\title{
Implementation of Algorithm to Protect Data from Different Attacks at Application Layer
}

\author{
Pooja Dahiya $^{1}$, Sonal $^{2}$ \\ Student, M.Tech (CSE), B.P.S.M.V., Khanpur Kalan, Sonipat (131305), Haryana, India ${ }^{1}$ \\ Assistant Professor, Department of CSE \& IT, B.P.S.M.V., Khanpur Kalan, Sonipat (131305), Haryana, India ${ }^{2}$ \\ Poojadahiya902@gmail.com ${ }^{1}$,sonalkharb@gmail.com ${ }^{2}$
}

\begin{abstract}
Network security is mechanism that is providing authorization to user to access the resources remotely. But there are several threats to existing network security. This paper present the implementation of algorithm used to protect data from different type of attacks at application layer. Security is a major concern for safe communication between mobile nodes in an alien environment. Network security has considered the authorization of access to information that is transferred over network. This information has been managed by network administrator. It is becoming significant to users as well as companies. Firewall is forcing to access policies in such a way that users could access services after getting authentication. After development \& testing of proposed work, comparative analysis between existing \& proposed work have discussed the security mechanism at application layer.
\end{abstract}

Keywords: Network Security, Application Layer, Data Protection, IDS, Cryptography

\section{INTRODUCTION}

Network security provides authorization with username as well as password. The Network security consists of provisions policies. These policies have been adopted by a network administrator. The objective is to monitor and prevent misuse and unauthorized access. It also restricts alteration in system, or denial of computer resources that could be accessed over network. Network security considers the authentication information access that is transferred over network. This transmission is managed by network administrator. Security is significant for users and companies [1] that work on network. Firewall is forcing to access policies in such a way that users could access services after getting authentication. Because to check unauthentic entry to system. Such element may be unable to restrict computer worms or Trojans. These are transmitted on the network. The Antivirus software or IDS is helping to detect malware [2]. Communication among nodes that are utilizing a network could use cryptography in order to set the privacy policy.

\section{RELATED WORK}

In this section a review of various researches made by different authors has been made. Some authors have made a review on password cracking strategies and password stealing attacks \& its protecting mechanism. Some of them discussed Identity Based Attack Detection and Localization by Clustering in Wireless Sensor Network. Several researchers have discussed security issues in protocols of TCP/IP Model at Layers Level and presented a review on Data Security, challenges and research Opportunities. Many of them explored database security and did study on threats \& attacks. Benefits as well as limitation along with techniques discussed by researcher present in table (1).
Table 1 -Chart of existing researches

\begin{tabular}{|c|c|c|c|c|c|}
\hline $\begin{array}{l}\mathbf{S} \\
\mathbf{r} \\
\mathbf{N}\end{array}$ & $\begin{array}{l}\text { Auth- } \\
\text { or }\end{array}$ & $\begin{array}{l}\text { Yea } \\
\mathbf{r}\end{array}$ & Technique & Benefits & $\begin{array}{l}\text { Limitati } \\
\text { ons }\end{array}$ \\
\hline 3 & $\begin{array}{l}\text { Bhawa } \\
\text { n } \\
\text { Bhardw } \\
\text { aj et al. }\end{array}$ & $\begin{array}{l}201 \\
7\end{array}$ & $\begin{array}{l}\text { Ad hoc } \\
\text { network }\end{array}$ & $\begin{array}{l}\text { Provide } \\
\text { security } \\
\text { for packet } \\
\text { sniffer, } \\
\text { brute } \\
\text { force, } \\
\text { man in } \\
\text { middle, ip } \\
\text { spoofing, } \\
\text { ip level } \\
\text { security. }\end{array}$ & $\begin{array}{l}\text { Does not } \\
\text { provide } \\
\text { security } \\
\text { for } \\
\text { intrusion } \\
\text { detection }\end{array}$ \\
\hline 4 & $\begin{array}{l}\text { Alband } \\
\text { ari } \\
\text { Mishal } \\
\text { Alotaib } \\
\text { i et al. }\end{array}$ & $\begin{array}{l}201 \\
7\end{array}$ & $\begin{array}{l}\text { TCP/IP } \\
\text { Model }\end{array}$ & $\begin{array}{l}\text { Security } \\
\text { issues in } \\
\text { Protocols } \\
\text { of TCP/IP } \\
\text { Model at } \\
\text { Layers } \\
\text { Level } \\
\text { have been } \\
\text { resolved. }\end{array}$ & $\begin{array}{l}\text { Does not } \\
\text { provide } \\
\text { solution } \\
\text { for denial } \\
\text { of } \\
\text { services. }\end{array}$ \\
\hline 5 & $\begin{array}{l}\text { Ganesh } \\
\text { Shanka } \\
\text { r Pote } \\
\text { et al. }\end{array}$ & $\begin{array}{l}201 \\
6\end{array}$ & $\begin{array}{l}\text { Database } \\
\text { security }\end{array}$ & $\begin{array}{l}\text { Study } \\
\text { made on } \\
\text { Threats \& } \\
\text { Attacks } \\
\text { on } \\
\text { Database } \\
\text { Security. }\end{array}$ & $\begin{array}{l}\text { Focus on } \\
\text { database } \\
\text { only. }\end{array}$ \\
\hline 6 & $\begin{array}{l}\text { Tuhin } \\
\text { Das et } \\
\text { al. }\end{array}$ & $\begin{array}{l}201 \\
6\end{array}$ & $\begin{array}{l}\text { Clustering } \\
\text { in Wireless } \\
\text { Sensor }\end{array}$ & $\begin{array}{l}\text { Identity } \\
\text { based } \\
\text { attack }\end{array}$ & $\begin{array}{l}\text { Threat } \\
\text { from } \\
\text { intrusion }\end{array}$ \\
\hline
\end{tabular}




\begin{tabular}{|c|c|c|c|c|c|}
\hline & & & Network & resolved & detection \\
\hline 7 & $\begin{array}{l}\text { Amand } \\
\text { eep } \\
\text { Kaur et } \\
\text { al. }\end{array}$ & $\begin{array}{l}201 \\
6\end{array}$ & $\begin{array}{l}\text { Wireless } \\
\text { Sensor } \\
\text { Network }\end{array}$ & $\begin{array}{l}\text { Provide } \\
\text { security to } \\
\text { wireless } \\
\text { sensor } \\
\text { network }\end{array}$ & $\begin{array}{l}\text { Require } \\
\text { ment to } \\
\text { upgrade } \\
\text { the } \\
\text { security }\end{array}$ \\
\hline 8 & $\begin{array}{l}\text { Venkad } \\
\text { esh .S } \\
\text { et al. }\end{array}$ & $\begin{array}{l}201 \\
5\end{array}$ & $\begin{array}{l}\text { Password } \\
\text { Stealing } \\
\text { Attacks }\end{array}$ & $\begin{array}{l}\text { Security } \\
\text { to } \\
\text { password } \\
\text { has been } \\
\text { proposed }\end{array}$ & $\begin{array}{l}\text { Threat } \\
\text { from } \\
\text { denial of } \\
\text { services }\end{array}$ \\
\hline 9 & $\begin{array}{l}\text { E } \\
\text { Bertino } \\
\text { et al. }\end{array}$ & $\begin{array}{l}201 \\
4\end{array}$ & $\begin{array}{l}\text { Data } \\
\text { Security }\end{array}$ & $\begin{array}{l}\text { Data } \\
\text { Security - } \\
\text { Challenge } \\
\text { s and } \\
\text { Research } \\
\text { Opportuni } \\
\text { ties have } \\
\text { been } \\
\text { discussed. }\end{array}$ & $\begin{array}{l}\text { Need of } \\
\text { more } \\
\text { technical } \\
\text { work. }\end{array}$ \\
\hline $\begin{array}{l}1 \\
0\end{array}$ & $\begin{array}{l}\text { Amand } \\
\text { eep } \\
\text { Kaur et } \\
\text { al. }\end{array}$ & $\begin{array}{l}201 \\
4\end{array}$ & $\begin{array}{l}\text { Mobile Ad- } \\
\text { hoc } \\
\text { Networks }\end{array}$ & $\begin{array}{l}\text { Provide } \\
\text { security to } \\
\text { mobile } \\
\text { ad-hoc } \\
\text { network }\end{array}$ & $\begin{array}{l}\text { Require } \\
\text { ment to } \\
\text { enhance } \\
\text { the } \\
\text { security }\end{array}$ \\
\hline $\begin{array}{l}1 \\
1\end{array}$ & $\begin{array}{l}\text { Ms. } \\
\text { Vidya } \\
\text { Vijayan } \\
\text { et al. }\end{array}$ & $\begin{array}{l}201 \\
4\end{array}$ & $\begin{array}{l}\text { Password } \\
\text { Cracking } \\
\text { Strategies }\end{array}$ & $\begin{array}{l}\text { Strong } \\
\text { password } \\
\text { mechanis } \\
\mathrm{m} \text { has } \\
\text { been } \\
\text { proposed }\end{array}$ & $\begin{array}{l}\text { There is } \\
\text { still } \\
\text { threat of } \\
\text { brute } \\
\text { fource } \\
\text { attack }\end{array}$ \\
\hline $\begin{array}{l}1 \\
2\end{array}$ & $\begin{array}{l}\text { Ashwin } \\
\mathrm{i} \quad \mathrm{R} . \\
\text { Tonde } \\
\text { et al. }\end{array}$ & $\begin{array}{l}201 \\
4\end{array}$ & $\begin{array}{l}\text { Encryption } \\
\text { Standard } \\
\text { Algorithm }\end{array}$ & $\begin{array}{l}\text { Security } \\
\text { during } \\
\text { data } \\
\text { transmissi } \\
\text { on has } \\
\text { been } \\
\text { enhanced. }\end{array}$ & $\begin{array}{l}\text { Research } \\
\text { does not } \\
\text { provide } \\
\text { solution } \\
\text { for } \\
\text { packet } \\
\text { dropping. }\end{array}$ \\
\hline $\begin{array}{l}1 \\
3\end{array}$ & $\begin{array}{l}\text { Mukun } \\
\text { d R. } \\
\text { Joshi et } \\
\text { al. }\end{array}$ & $\begin{array}{l}201 \\
3\end{array}$ & $\begin{array}{l}\text { Cryptograph } \\
\text { y }\end{array}$ & $\begin{array}{l}\text { Enhance } \\
\text { ment of } \\
\text { network } \\
\text { security } \\
\text { using } \\
\text { cryptogra } \\
\text { phic }\end{array}$ & $\begin{array}{l}\text { Does not } \\
\text { provide } \\
\text { solution } \\
\text { in case of } \\
\text { ping of } \\
\text { death }\end{array}$ \\
\hline $\begin{array}{l}1 \\
4\end{array}$ & $\begin{array}{l}\text { Rupam, } \\
\text { Atul } \\
\text { Verma } \\
\text { et al. }\end{array}$ & $\begin{array}{l}201 \\
3\end{array}$ & $\begin{array}{l}\text { Packet } \\
\text { Sniffing }\end{array}$ & $\begin{array}{l}\text { Provide } \\
\text { security } \\
\text { for packet } \\
\text { sniffer } \\
\text { and man } \\
\text { in middle } \\
\text { attack }\end{array}$ & $\begin{array}{l}\text { Does not } \\
\text { provide } \\
\text { security } \\
\text { for brute } \\
\text { force } \\
\text { intrusion } \\
\text { detection }\end{array}$ \\
\hline $\begin{array}{l}1 \\
5\end{array}$ & $\begin{array}{l}\text { Wajeb } \\
\text { Gharibi }\end{array}$ & $\begin{array}{l}201 \\
2\end{array}$ & $\begin{array}{l}\text { Cyber } \\
\text { threats }\end{array}$ & $\begin{array}{l}\text { Provide } \\
\text { security }\end{array}$ & $\begin{array}{l}\text { Does not } \\
\text { provide }\end{array}$ \\
\hline
\end{tabular}

\begin{tabular}{|l|l|l|l|l|l|}
\hline & et al. & & & $\begin{array}{l}\text { for } \\
\text { intrusion } \\
\text { detection }\end{array}$ & $\begin{array}{l}\text { security } \\
\text { for brute } \\
\text { force } \\
\text { packet } \\
\text { sniffer }\end{array}$ \\
\hline 1 & $\begin{array}{l}\text { Mr. } \\
\text { Atul M. } \\
\text { Borkar } \\
\text { et al. }\end{array}$ & 1 & Algorithm & $\begin{array}{l}\text { Strong } \\
\text { encryptio } \\
\text { n } \\
\text { mechanis } \\
\text { m has has } \\
\text { been } \\
\text { proposed }\end{array}$ & $\begin{array}{l}\text { Need to } \\
\text { provide } \\
\text { security } \\
\text { from } \\
\text { packet } \\
\text { sniffer } \\
\text { attack }\end{array}$ \\
\hline 1 & $\begin{array}{l}\text { Shahria } \\
\text { r } \\
\text { Moham } \\
\text { madi et } \\
\text { al. }\end{array}$ & $\begin{array}{l}201 \\
\text { l. Link Layer }\end{array}$ & $\begin{array}{l}\text { Provide } \\
\text { security } \\
\text { for man in } \\
\text { middle } \\
\text { attack }\end{array}$ & $\begin{array}{l}\text { Does not } \\
\text { provide } \\
\text { security } \\
\text { for } \\
\text { packet } \\
\text { sniffer, } \\
\text { brute } \\
\text { force, }\end{array}$ \\
\hline
\end{tabular}

\section{PROPOSED WORK}

Proposed work is enhancement of security system in order to protect from different attacks at application layer. There is requirement to develop a server \& client application in order to secure data at application layer. Encoded data is transmitted to client at receiver end decoded data is captured.

\subsection{Existing Algorithm}

The process of encryption utilizes a group of particularly derived keys called round keys. The following steps were taken to encrypt a one hundred twenty eight bits (128bits) block [18].

Step1: Cipher key generate by the group of round key.

Step 2: Set the condition array within block data.

Step3: Join first key to beginning state array.

Step4: Perform Copy operation of final state array out as encrypted data.

\subsection{Bit Shifting Process Along With Xor Operation}

$\mathrm{S}^{\prime} 1, \mathrm{C}=63 \oplus(\{02\} . \mathrm{CO}) \oplus(\{03\} . \mathrm{FE}) \oplus 9 \mathrm{C}$

$(\{02\} . \mathrm{CO})=11000000<<1$ (1 Shift to the left)

$=10000000$

$10000000 \oplus 00011011=10011011$

(xor ed with " 00011011 " because lost high bit of 1 in the shift)

$(\{03\} . \mathrm{FE})=11111110<<1$

$=11111100$

$11111100 \oplus 00011011=11100111$

(xor ed with " 00011011 " because lost high bit of 1 in the shift)

$11100111 \oplus 11111100=00011011$

$63=01100011$

9C $=10011100$ 
$10011011 \oplus 00011001 \oplus 01100011 \oplus 10011100=01111101=$ $7 \mathrm{D}$

\subsection{Proposed Algorithm}

\section{ALGORITHM AT SENDER END}

The steps of proposed algorithm at sender end are as under:Step 1: Internet Protocol filter has been utilized to ignore the invalid packet transmission from server to client. If packet is valid then enhanced AES ENCRYPTION module works. This step restricts the intruder.

Step2: In this step enhancement of network security is done by modifying present encryption mechanisms.

The working of AES at sender end is as following:-

I. TAKE PLAIN TEXT (256 bits)

II. APPLY ROUND KEY set counter=1

III. If counter is less then $\mathrm{N}-1$ (Here $\mathrm{N}$ would be number of iteration)
a) Process sub byte.
b) Perform Shift row
c) Mix columns
d) counter=counter +1 ;

IV. other wise

a) Sub bytes process

b) Then row shift

c) Then round key apply

V. Cipher text would be generated (256 bits)

Step 3: Perform Data Transmission

\section{ALGORITHM AT RECEIVER END}

The steps of proposed algorithm at receiver end are as under:-

Step 1: Receive the data.

Step 2: Perform decryption of data at receiver end

$\begin{aligned} \text { i. } & \text { TAKE CIPHER TEXT (256 bits) } \\ \text { ii. } & \text { APPLY ROUND KEY set counter=1 } \\ \text { iii. } & \text { if counter is less then N-1 }\end{aligned}$

a) Process Inverse shift row.

b) Perform inverse sub byte

c) Inverse mix columns

d) Counter=counter+1;

iv. other wise
a) Inverse shift rows
b) Inverse sub byte
c) Apply round key
v. Plain text would be generated (256 bits)

\subsection{Comparison Of Existing Algorithm With Proposed Work}

In case of existing work there was security of data at application layer only. Due to limitation of existing security mechanisms there was need to develop a new security system. In proposed work security has been provided to packet and chance for decryption without authentication should get reduced. There is need to implement IP filter based security in order to prevent attacker from different network would enhance Advanced Encryption Standard by introducing multilayer security.
Brute Force attack is removed in the proposed algorithm as data is transferred during specific session. Attacker who is using brute force attack would not be capable to detect when then port to receive data has been opened on receiver end.

\subsection{Process Flow}

The process flow of proposed work has been discussed in following diagram. Here sender generated packet is transferred for IP validation. If packet is arriving from valid IP then drop packet and stop otherwise packet would be encrypted and transmission is made. On receiving end the data would be decrypted and plain text would be provided to receiver.

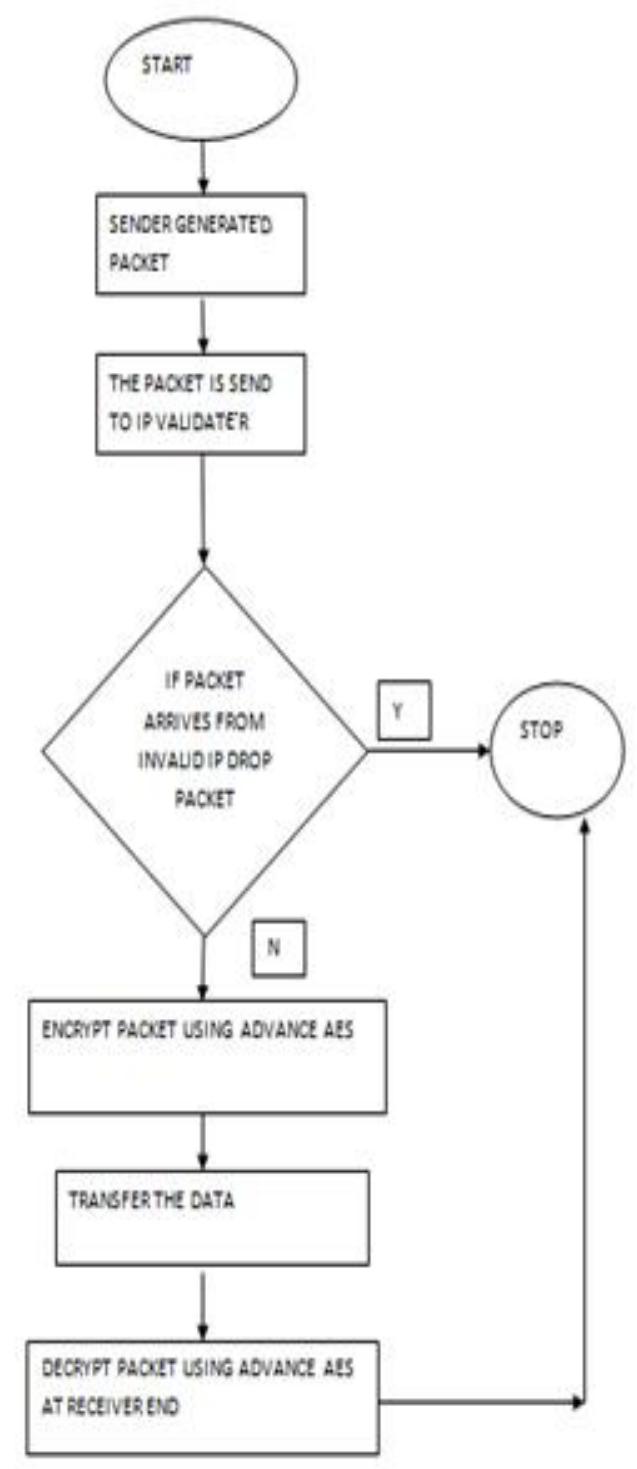

Fig 1: AES at sending and receiving end 


\section{RESULTS}

\section{GUI INTERFACE FOR CLIENT}

This is the file sender interface that would send data to the server. Here the user id, password, port number, IP address, path of file to be send along with security token and AES CODE.

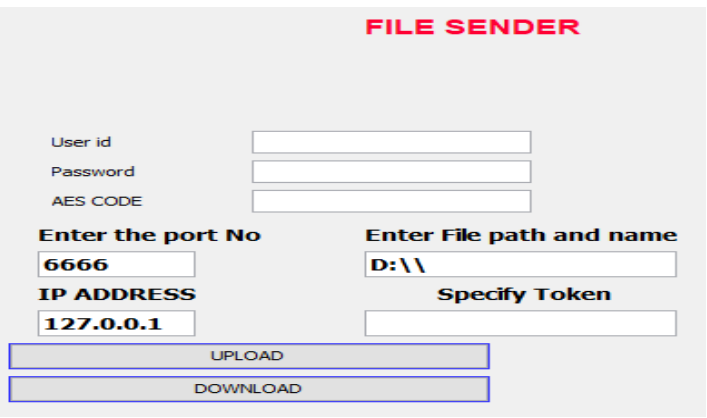

Fig 2: Sender Side Application

\section{GUI INTERFACE FOR SERVER}

This is the file sender interface that would send data to the server. Here the port number, AES CODE, path of file to be received along with security token.

\section{File Reciever}
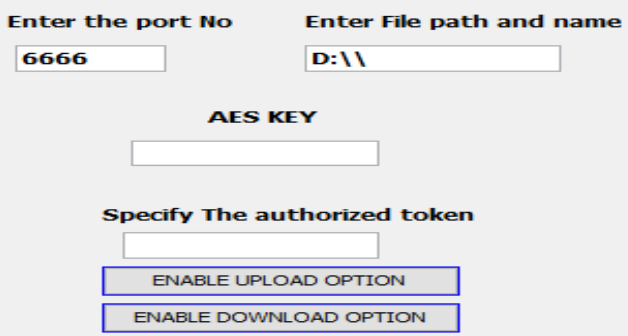

Fig 3: Receiver side Application

\section{FILE FOR TRANSFER}

Following file would be transferred to the receiver from sender end. It may be notepad file.

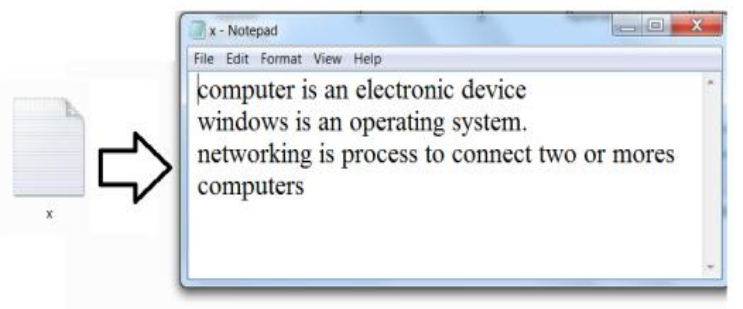

Fig 4: Transfer for File

\section{FILE RECEIVED}

Following file would be received at the receiver end. The content of that file would be same as file sent from sender end.

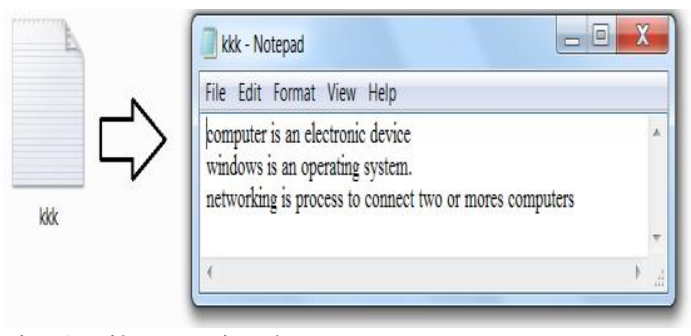

Fig 5: File Received

ENCRYPTED FILE

Here we have represented the content of file during transmission. It is cipher text that is not readable. If any person is going to hack that information then he would be unable to understand it.

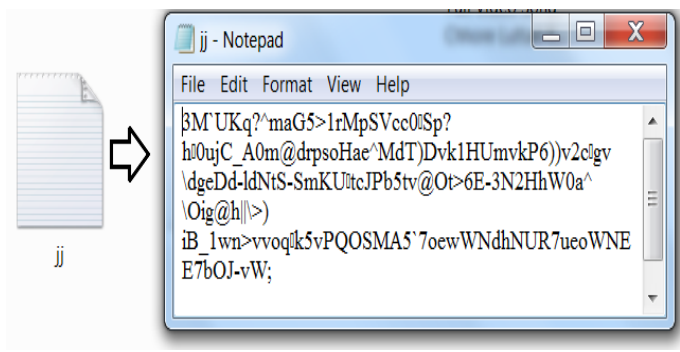

Fig 6: Encrypted File

\subsection{Getting Data for Simulation}

The simulation of data transmission result in following data:-

\section{PACKET DROPPING}

Packet dropping table (2) has been generated by considering the difference between packet sent and packet received during above java based packet transmission simulation.

\section{Packet dropping $=$ Packet sent-Packet received}

\section{TIME TAKEN TO TRANSFER DATA}

Time taken to transfer data table (3) has been generated by considering the difference between receiving time and sending time during above java based packet transmission simulation. Time taken to transfer data is calculated by following equation

\section{Time Taken $=$ Receiving time-Sending time ERROR RATES}

Error rate has been influenced by packet dropping table (4) generated during above sending receiving data transmission module. It is influenced by several factors such as type of data, size of data, transmission media, number of processes, technical issues.

\section{Error Rate $=$ Number of Errors / Number of Packets PACKET SIZE}

The size of packet has been reduced during encryption in order to reduce the chances of congestion and errors. This table (5) has been generated during above sending receiving data transmission module.

\subsection{Simulation in Matlab Introduction To Matlab Tool}




\section{Available online at www.ijrat.org}

The simulation has been made in MATLAB 2018 b. MATLAB is mathematical laboratory. Here the simulation is made by collecting data from java based socket programming in text file and MATLAB script have been

\section{COMPARATIVE ANALYSIS OF PACKET DROPPING IN EXISTING AND PROPOSED WORK}

When data is transferred over network there is always probability of attack and packet dropping. Here the comparison of packet dropping in case existing and proposed work has been made.

Table: 2 Packet dropping in existing and proposed work

\begin{tabular}{|l|l|l|}
\hline Packets & Existing & Proposed \\
\hline 100 & 5 & 3 \\
\hline 200 & 9 & 3 \\
\hline 300 & 10 & 4 \\
\hline 400 & 12 & 4 \\
\hline 500 & 14 & 7 \\
\hline 600 & 18 & 8 \\
\hline 700 & 30 & 12 \\
\hline 800 & 40 & 23 \\
\hline
\end{tabular}

Following is MATLAB based chart plotted to represent the comparative analysis of packet dropping between existing and proposed work.

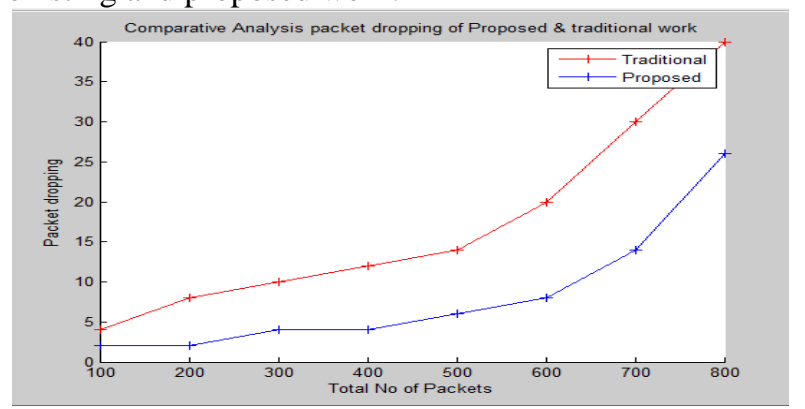

Fig 7: Comparative Analysis of Packet Dropping in Existing \& Proposed work

The above figure shows comparative analysis packet dropping in case of existing \& proposed work.

COMPARISON OF TIME TAKEN IN ORDER TO TRANSFER DATA

Following chart represents the time taken during transmission of data in case of existing and proposed work. This chart represents that the time taken are less as compare to existing work. Here the simulation is made considering packet size of $10,20,30,40,50$, and 60 respectively.

Table 3-Comparison of time taken to transfer data

\begin{tabular}{|l|l|l|}
\hline Packets & Existing & Proposed \\
\hline 10 & 1 & 0.7 \\
\hline 20 & 1.7 & 1.5 \\
\hline 30 & 2.3 & 1.7 \\
\hline 40 & 2.8 & 2.4 \\
\hline
\end{tabular}

written to plot diagram. Here MATLAB functions such as plot, hold on, title, x label, y label, legend have been used. MATLAB GUI tools have used for simulation.

\begin{tabular}{|l|l|l|}
\hline 50 & 3.8 & 2.9 \\
\hline 60 & 4.8 & 3.4 \\
\hline
\end{tabular}

Following is MATLAB based chart plotted to represent the comparative analysis of time taken between existing and proposed work.

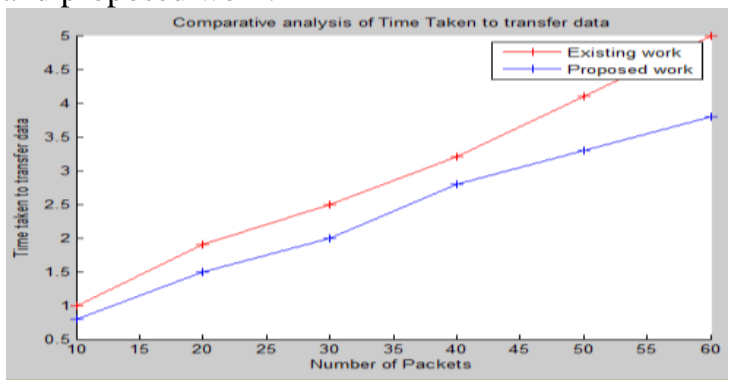

Fig 8: Comparison of Time Taken to Transfer Data

The above figure shows comparative analysis in case of existing \& proposed work. Details of time taken to transfer packet have been compared here.

\section{THE COMPARISON OF ERROR RATES DURING TIME OF TRANSFER DATA}

Following chart represents the error rates during transmission of data in case of existing and proposed work. This chart represents that the error rates are less as compare to existing work. Here the simulation is made considering packet size of $10,20,30,40,50$, and 60 respectively.

Table: 4 Comparison of error rates during time of transfer data

\begin{tabular}{|l|l|l|}
\hline Packets & Existing & Proposed \\
\hline 10 & 1 & 0.6 \\
\hline 20 & 1.5 & 1 \\
\hline 30 & 2.1 & 1.6 \\
\hline 40 & 2.6 & 1.8 \\
\hline 50 & 3.9 & 2.5 \\
\hline 60 & 4.2 & 3.5 \\
\hline
\end{tabular}

Following is MATLAB based chart plotted to represent comparative analysis between existing and proposed work.

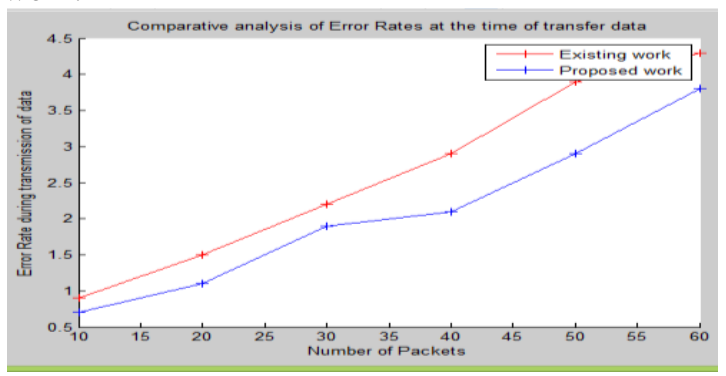

Fig 9: Comparison of Error Rates During Time of Transfer Data 


\section{Available online at www.ijrat.org}

This figure shows comparison of error rates during time of transfer data during existing \& proposed work.

\section{COMPARISON OF PACKET SIZE}

Following chart represents error rates during transmission of information in case of existing and proposed work. This chart represents that error rates are less as compare to to existing work. Here simulation is made considering packet size of $10,20,30,40,50$, and 60 respectively.

\begin{tabular}{|l|l|l|}
\hline Packets & Existing & Proposed \\
\hline 10 & 10 & 7 \\
\hline 20 & 14 & 10 \\
\hline 30 & 18 & 15 \\
\hline 40 & 28 & 17 \\
\hline 50 & 32 & 25 \\
\hline 60 & 41 & 30 \\
\hline
\end{tabular}

Table 5- Comparison of packet size

Following is MATLAB based chart plotted to represent comparative analysis between existing and proposed work

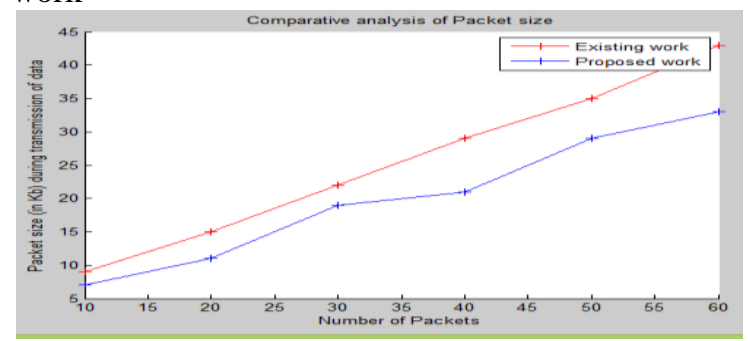

Fig 10: Comparison of Packet Size

This figure is displaying comparison of packet size in case of existing as well as proposed work.

\section{FUTURE SCOPE}

The results of work show that in case of secure transmission speed of data transmission is reduced if length of packet is minimized. The speed of data transmission may increase in contrast of secure existing work if packet size is reduced. With the expansion of internet, the security of network is gaining attention increasingly. The protocols of security threats of internet were examined to decide which type of security technology is required. Security technology is mostly based on the software. It uses many general hardware devices. The development in today's time in Security of network is not considerable. Hence proposed work would play important role in enhancing security of data.

\section{REFERENCES}

[1] M. Malik, T. Patel, "Database Security - Attacks and Control Methods", International Journal of Information Sciences and Techniques (IJIST) Volume.6, No.1/2, March 2016,pp.175-183.

[2] D. Andriy, P. Gulia, "Critical Review of Security Attacks in Wireless PAN", International Journal of
Computer Applications, Volume 160 - No 1, February 2017,pp.15-19.

[3] B. Bhardwaj, A. Mittal, "Advanced Mechanisms to Secure Wireless ad hoc network with performance Analysis", Volume: 08 Issue: 08, October - December 2017.

[4] A. M. Alotaibi, B. F. Alrashidi, S. N. Z. Parveen, "Security issues in Protocols of TCP/IP Model at Layers Level", International Journal of Computer Networks Communications Security, Volume. 5, No. 5, May 2017, pp. 96-104.

[5] G. S. Pote, A. Giri, "Database Security: A Study on Threats \& Attacks", International Journal on Recent and Innovation Trends in Computing and Communication, Volume: 4 Issue: 6, June 2016, pp. $512-513$

[6] T. Das, "A Study on Identity Based Attack Detection and Localization by Clustering in Wireless Sensor Network", International Journal of Computer Sciences and Engineering Open Access, Volume-04, Issue-02, Feb 2016, pp. 96-99.

[7] A. Kaur, S. S. Kang, "Attacks in Wireless Sensor Network- A Review", International Journal of Computer Sciences \& Engineering, Volume.04, Issue 05, May 2016, pp.157-162.

[8] Venkadesh .S, K. Palanivel , "A Survey on Password Stealing Attacks \& Its Protecting Mechanism", International Journal of Engineering Trends \& Technology (IJETT), Volume 19, Number 4, Jan 2015, pp.223-226.

[9] E. Bertino, "Data Security - Challenges and Research Opportunities", Springer International Publishing Switzerland, 2014, pp. 9-13.

[10] A. Kaur, Dr. A. Singh, "A Review on Security Attacks in Mobile Ad-hoc Networks", International Journal of Science \& Research, Volume 3, Issue 5, May 2014, pp.1295-1299.

[11] V. Vijayan, Ms. J. , Mrs. Suchithra, "A Review on Password Cracking Strategies", International Journal of Research in Computer \& Communication Technology, 2014, pp.8-15.

[12] A. R. Tonde , A. P. Dhande, "Implementation of Advanced Encryption Standard (AES) Algorithm Based on FPGA", International Journal of Current Engineering and Technology, Vol.4, No.2 April 2014, pp.1048-1050.

[13] M. R. Joshi, R. A. Karkade, "Network Security with Cryptography", International Journal of DDOS Attack Using Time series Analysis", Journal of Control Science \& Engineering,2013, pp.1-6.

[14] Rupam, A. Verma, A. Singh, "An Approach to Detect Packets Using Packet Sniffing, International Journal of Computer Science \& Engineering Survey (IJCSES), Volume.4, No.3, June 2013, pp.21-33

[15]W. Gharibi, M. Shaabi, "Cyber threats in social networking websites", International Journal of Distributed \& Parallel Systems (IJDPS), Volume.3, No.1, January 2012, pp. 119-126. 


\section{Available online at www.ijrat.org}

[16] Atul, M. Borkar, R. V. Kshirsagar, M. V. Vyawahare, "FPGA Implementation of AES Algorithm", IEEE, 2011, pp.401-405.

[17] S. Mohammadi, R. E. Atani, H. Jadidoleslamy, “A Comparison of Link Layer Attacks in Wireless Sensor Networks", Journal of Information Security, April 2011, pp. 69-84.

[18] Anju, Babita, Reena, A. Aggarwal ,“An Approach to Improve the Data Security using Encryption and Decryption Technique", International Journal of Information and Computation Technology, Volume 3, Number 3, 2013, pp. 125-130. 